that just where a water-pipe passed orcr a sewer, there the pipe was defective, and as a consequence a serious epidemic arose. Sewago soon decomposes iron; and if water-pipes be allowed to lie in sewers, and to occupy portions of eesspits on the roadside, or to be in communication at those points at which water is delivered into a house and slops and sewage removed, there can be no real safety for the people. I an sometimes astounded when I hear men who put themsclves forward as Sanitary anthorities atterly ignore this fundamental law.

The seventh law is that the individual house is the unity of Sanitary work, that it is in each house, and it is with each individual that the first action must be taken to diminish the power of $z$ to grow and prodace its kind, whilst should $z$ be introduced, it is the individual case which is the unit of repression. But all these canon laws have their foundation upon the particulate nature of contagia, and it is by bearing this one fact in mind that Sanitary work can produce sufficient fruit to be successful.

Alfred Carpenter, m.d. Lond., President of Section.

\title{
On Certain Points with reference to Drinking-Water.
}

Moch controversy has taken place with reference to the subject of drinking-water, and indeed we may say that no part of the wide field of Hygiene has formed more frequently the battle-ground of the partizans of different theories. Many things have contributed to this: a too great tendency to generalization from insufficient data; a too great dependence upon the dogmatic opinions from time to time enunciated; - $\Omega$ tendency to misreprescnt the views of opponents, \&c. All those things retard true progress and are apt to bring hygiene more or less into discredit. Thus it is asserted by some who are opposed to the so-called "water theory" of discase, that its supporters insist that this is the only means of propagation. I need hardly point out that this is erroncous, for I am not aware that this has ever been insisted opon by any one whose opinion has carried any weight with it. Another accusation is this: that, by demanding the presence of a germ or materies morti in water, as a sine qua non for the production of a specific disorder, the science of hygiene is actually retarded and attention drawn away from the necessity of having pure water at all times. Here again is, I think, a mis-statement of the case, for no one has advocated the use of impure water (if we except the address of the late Sir William Ferguson, which was an instance of an eminent man stepping out of his way to treat a subject which he had not sufficiently con- 
sidered). But, on the other hand, we have been obliged to admit that in some, perhaps indeed many, instances, water undoubtedly impure has been consumed for a length of time, without positive disease being directly traceable to it. Still that is no reason why impure water should be used, and none are likely to recommend it. For we are all ready to admit, to some extent at least, two points, viz. - 1. An impure water is probably more likely to form a favourable nidus for disease-poison, whatever that may be, than a pure one; and 2. It is, at least, not unlikely that the prolonged use of an impure water renders an individual more open to attacks of disease, should he be exposed to them. But there is also another side to the question: there exist cases, where the evidence secms fairly convincing, that disease has been propagated by means of water which our present means of examination fail to detect the impurity of. But in this there is nothing contradictory, for assum. ing for a moment the verisimilitude of the germ theory, we recognize the extraordinary minuteness of some of the bacteroid points, which tax the powers of our best microscopes to recognize them. Should these organisms be propagated by means of conidia, how much more minute must they be! And if, as has been suggested by Mr. Sorby, we have already reached the greatest power of penetration by means of lenses, it is quite conceivable that wo may never see a germ, even supposing it positively exists. It will also be evident that, if microscopic investigation fail to reveal its existence, still less can we hope much from chemistry in this direction.

It must not, however, be nnderstood from these remarks that I look upon either chemical or microscopical research in this direction as valueless; on the contrary, I think they are of very consiclerible value, but the value has, in my opinion, been both overrated and anderrated. Thus, it has been overrated when chemists havo proposed to lay down certain hard-and-fast lines as to the quantity of constituents to be considered as arlmissible; whilst it has been underrated by those who, disgusted and discouraged by an overweening dogmatism, have given up chemistry and the microscope in despair. What, then, is the position that the examination of water occupies at the present time? First, with reference to the chemical question. The most important is undoultedly the quantity and nature of the organic matter, and any condition of the water that may influence its changes or action. Various plans for its estimation have been adopted, but I purpose to direct attention only to the so-called albuminoid ammonia method, and to the use of the permanganate of potassium. Those two are the easiest of application on the whole, and if intelligently applied they give information of some value. The former plan has been extensively usel in this country, the latter being more commonly employed abroad. Following the limits laid down by Professor Wanklyn, it has been customary to adopt 0.08 of a part per million as the limit of albuminoid ammonia in a first-class drinking water, any waters going beyond 0.10 being considered as dirty waters. Indeed, Mr. Wanklyn goes so far as to look suspiciously upon a water with moro than 
0.05 , if there is a notable amount of free or saline ammonia. In a good many instances this rule has been applied with some rigour, and water has been condemned unhesitatingly when judged by it. But it is obvious that this method tells us little or nothing of the nature of the organic matter, and, chietly, whether it be vegetable or animal. When the albuminoid ammonia is well marked and we have at the same time a good deal of free ammonia, the conclusion usually drawn is that the contamination is animal; on the other hand, in the absence of the free ammonia, it is assumed to be vegetable; and the qucstion is still further modified by the presence or absence of chlorine. But, supposing we do assume that the organic matter is regetable, is this sufficient? By no means; in some cases vegetable matter has been shown to be at least probably hurtful, in the way of inducing diarrhoea, \&c.; but in others a considerable quantity may exist without any harm resulting. This is especially the case with peat-waters, which contain a large amount of albuminoid ammonia, and would be condemned by some chemists on that account, If we did so, however, we should have to condemn a large part of the water-supply in Ireland, and, in my opinion, very unrensonably. For instance, a number of samples from that country have como from time to time into my hands, with reference to the water supply for the troops; but where I was satisfied that the organic matter was of peaty origin, I have not condemned the water, even although the albuminoid ammonia was large. Thus: a sample from the water-works supply at Waterford yielded no free ammonia, but 0.28 of albuminoid: samples of the Vartry supply from Dublin Barracks yielded 0.132 and 0.156 of albuminoid without any free ammonia. I am afraid some chemists would have condemned those samples, but feeling satisfied that it was vegetable matter, I did not feel myself justified in doing moro than pointing out that the filtration at the Company's works was imperfect, as indicated by the somewhat numerous organisms shown by the microscope. Again, with reference to the permanganate test; this we generally use at Netley with sulphuric acid and heat, reckoning the results as so much oxygen required for the destruction of the organic oxidizable matter, taking care to separate this from the nitrous acid. As a limit, 1.0 milligramme per litre may be laid down as a general guide, but much latitude must be allowed : thus the pent-waters above allucled to yielded from 1.14 in the Vartry to 3.0 in the Waterford supply. Such a quantity wonld be very objectionable with animal impurity, but is probably innocuous with vegetable.

It may therefore be stated as a gencral principle, roughly applicable, that, if we can be fairly assured that the impurity in a sample of drinking-water is vegetable, the limits usually laid down may be considerably exceeded without it being incumbent on us to condemn the water. But now comes a second question. Is this true of all vegetable matter? We may take it as generally true of peat or moorland waters, but under some circumstances it may not be true. It would, for instance, not be true in the case of contaminations from marshes of a malarious charncter, where I shonld 
be inclined to make the limitation decidedly narrow; or in contamination with vegetable matter from malarions districts, such as is reported by Dr. Smart in the Rocky Mountains country, or where poisonous plants abound, \&c. In the case of the Leek workhouse, Professor Wanklyn believed diarrhœe to have been caused by vegetable contamination; this may have been the case, but the evidence seems inconclusive.

The next point of importance is the significance of free ammonia, or saline ammonia, as it is sometimes called. Here the limit has been put very low, only 0.02 parts per million. When present along with albuminoid ammonia, but without much chlorine, it is taken to show contamination with sewer-gas as probable; with a marked amount of chlorine and albuminoid ammonia, contamination with sewage; with little or no albuminoid ammonia, but with a good deal of chlorine, contamination with urine; with neither albuminoid ammonia nor chlorine, vegetable, perbaps marsh, contamination. Even assuming that those inferences are correct, it is obvious that two or more of the conditions might co-exist and so interfere with the diagnosis. But is it certain that they are correct? Not in all, I think, particularly where urinous contamination is assorted of waters containing much free ammonia and chlorides, but without albuminoid ammonia. These characters are met with not unfrequently in deep wcll-waters-Artesian wells, in fact, where recent contamination cannot be urged. Thus the well in Trafalgar Square yields (per million) about 0.85 of free ammonia and 165.5 of chlorine ( $=11.515$ grains per gallon); and its analysis, I believe, at first caused Professor Frankland to have suspicions of sewage contamination. But other wells are found to yicld similar results. Thus : two samples from deep wells (about $240 \mathrm{ft}$.) at Parkhnrst yielded, respectively, 0.924 and 0.936 parts per million of free ammonia - no albuminoid ammonia in one case, and only a trace in the other, and from four to five grains of chlorine per gallon. Contamination is hardly to be thought of. But perhaps one of the most curious is the instance of the Spithead Forts. From a well sunk in the outermost one, at a distance of at least two miles from land, a sample was sent to me: it contained 0.5428 per million of free ammonia, no albuminoid, and about 3.9 (grains per gallon) of chlorine. Contamination here is out of the question. But where does this free ammonia come from? It is not possible to say positively, but in all likelihood from some organic matter which has undergone conversion into ammonia, but has not passed into the farther stage of nitric acid. The experiments of Schliessing apd Munz, and of Warington, have confirmerl the suggestion of Pasteur, that nitrification is a fermentative process, requiring a peculiar organized ferment for its operation,-the addition of substances known to be fatal, or at least obstructive, to low forms of life being efficacious in arresting the process. In the samples in question, especially in that from Spithead, there was no sign of animal or vegetable life on microscopic examination, and we may therefore conclude that the persistence of the nitrogen in the form of ammonia was due to the absence of the ferment necessary to 
complete the process of nitrification. This seems to me the most probable explanation of the apparent contamination of deep-well waters, which has been a source of puzzle to a good many people.

The above remarks tend to show that, in addition to the mere chemical knowledge of the constituents, information as to the source, its nature and surroundings, and in fact as much as we can possibly get about the water, are necessary to form a correct judgment. At the same time, the laying down of certain limitations as to quantities is useful as a foundation to work upon, and this may be seen by a reference to the table, which shows the mean of 223 samples analyzed and reported upon at Netley. Of those fifty-four were pronounced to be "fit for use," that is, no excessive impurity could be detected chemically; 103 were pronounced "usable," or "required filtration;" and sixty-six were positively condemned. It will be seen that the class of "fit" lies well within the limits laid down with reference to organic constituents, and that there is a progressive increase in tho two other classes. Eren in the chlorine this is also observable.

Table of the Average Amounts of Constituents in Drinking-Water according to Class. Mean of 223 samples.

\begin{tabular}{|c|c|c|c|c|c|c|c|}
\hline \multirow[b]{2}{*}{ Class. } & \multirow{2}{*}{ 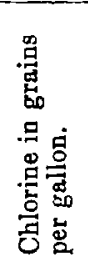 } & \multicolumn{2}{|c|}{$\begin{array}{l}\text { Ammonia in milli- } \\
\text { grammes per litre. }\end{array}$} & \multirow{2}{*}{ 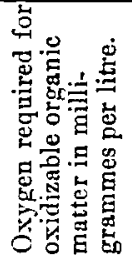 } & \multirow{2}{*}{ 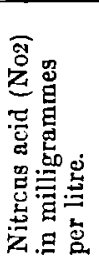 } & \multicolumn{2}{|c|}{$\begin{array}{c}\text { Hardness. } \\
\text { Clark's Scale. }\end{array}$} \\
\hline & & 迎 & 宫 & & & 离 & 吾 \\
\hline $\begin{array}{l}\text { "Fit for nse," } \\
\text { or free from } \\
\text { marked organic } \\
\text { impurity. } \\
\text { (54 samples.) }\end{array}$ & $2 \cdot 2045$ & 0.0050 & 0.0258 & 0.3611 & 0.2097 & 5.06 & 1225 \\
\hline $\begin{array}{l}\text { "Usable," } \\
\text { or requiring } \\
\text { filtration } \\
\text { before use. } \\
\text { (103 samples.) }\end{array}$ & $2 \cdot 3367$ & 0.0843 & 0.2062 & 0.8200 & 0.3430 & $5 \cdot 94$ & $11 \cdot 55$ \\
\hline $\begin{array}{l}\text { "Unfit for use,' } \\
\text { on account } \\
\text { of organic } \\
\text { impurity. } \\
\text { (66 samples.) }\end{array}$ & $1 \cdot 2612$ & 0.4783 & 0.4337 & 0.7977 & 0.5927 & $7 \cdot 71$ & $14 \cdot 68$ \\
\hline
\end{tabular}

Let us now say a word with reference to the mineral constituents. Here we find grounds for difference of opinion also, and it is much to be desired that some uniformity should be arrived at. At present wo have the unedifying spectacle of one analyst declaring a water 
fit for drinking, and another condemning it. A controversy of this kind is going on at this moment between two eminent chemists in London. It may be difficult to lny down any fixed rule, but something might, I think, be arrived at that would remove this discrepancy. Within some limits a difference of opinion is likely to exist, but surely a viâ media could be found here more easily than in the case of organic impurity. Some think a water of a certain hardness necessary, and condemn too soft water; others hold a dircetly opposite opinion. Some even recommend the addition of salt to water; others are inclined to condemn water with even a moderate quantity of salt. In ono case the sample is condemned by one chemist as unfit for washing, but allowed to be fit for drinking; whilst another condemns it for both purposes. I have myself a small experience in this direction. A series of samples lately submitted to me I felt obliged to condemn as an ordinary watersupply, on account of the large amount of mineral constituents, such as more than 140 grains per gallon of solids, of which at least 85 were chlorides and 10 were magnesia: fixed hardness 49 degrees of Clark's scale. Of this water I said that it might bo used in case of great emergency, but that as an ordinary watersupply it was very unadvisable, especially in the case of children or the sick, in whom it would be apt to proluce diarrhoea and perhaps aggravate other diseases. It was also, I reported, unfit for washing purposes on account of its hardness. I may mention that the source of the water was near the sea and that it was free from organic impurity. A sample was sent to an eminent analyst in London, whose analysis agreed in the main with my own; but the conclusion he drew was that it was a good water fit for all domestic purposes. Now, what is the public to think of those discrepancies? Is it likely that confidence will be placed in analysis, or is it a wonder that people should declare that chemists - water-analysts especially - and their work require rehabilitation?

On the other hand, difficulties arise, which analysts have to contend with, in ways that are but little appreciated by the public. For instance, I have had samples of rain-water sent to me, which proved full of various kinds of impurity; but I have had some difficulty in getting it admitted that such a thing was possible. "But it's rin-water!" people say : very trae, but still it is impare. We might further answer, that for the matter of that, all water is rain-water, but the preservation of its purity is a question of collection and storage, whether these be done by nature or by man. Of the cases of contamination that have come within my observation the following are a few : by spray from the sea, by soaking from salt marshes into the collecting tanks, by smoke products and house refuse, by taking up caustic lime from the cement of tanks, by pigeon-droppings from house roofs, \&c. These are only some, and not the most dangerous, sources of impurity. Another soarce of difficulty is carelessness in collection of the samples. A case illustrating this recently occurred to me. Samples from the top and from the bottom of a well were sent for examination, two bottles of each. The bottom sample and one of tho bottles of 
the top sample were fairly good, but the second bottle of the top sample was dirty and offensive, the sediment apparently consisting entirely of fatty matter. I reported that the two samples seemed from the same sonrce by the mineral analysis, but that probably something had got into the one in question at the time of collection, assuming the bottle to have been clean. On inquiry it turned out that to obtain the sample a man had to be sent down the well with a candle, the tallow of which had quietly dropped into the well and been carcfully bottled ofl' with the sample! Still another difficulty arises from want of care as regards clcanliness of the vessels in which the samples are sent. I have had some sent in old picklejars, castor-oil bottles, turpentine bottles, physic bottles of all sorts, with corks of a very ancient and fish-like smell. To analyze such samples is simply a waste of time.

The best of all examinations is that which is made by the analyst on the spot itself, at the very source of supply. If that be impossible, then the most scrupnlous care should be taken about the collecting of the sample and its transmission in clean glass-stoppered bottles, with every detail of information that can possibly be furnished.

I should have wished to say a few words about the microscopic examination of water, but my paper has reached the prescribed limits, and I will therefore merely urge the importance of not neglecting this branch of the inquiry. It may be said that it has not as yet done much for us-still it does furnish us with some information; and if we desire more, it is only by persistent observation and carefully noting what we see and the circumstances under which the objects are seen, that we are likely to extend our knowledge in this direction.

\section{Francis S. B. François de Chaumont, M.D., f.r s.}

\section{Interpretation of Water Analysis for Drinking Purposes.}

DR. Swete to some extent travelled over the same ground as Professor F. de Chaumont. The earlier portion of his paper was occupied with an account of the different processes employed for the determination of organic matter in water, and a discussion as to the value or advisability of each in a Sanitary point of riew. He then proceeds as follows:-

"Now having gained these chemical data, will they be sufficient without further observation or knowledge of the source of supply to enable us to give a reliable report? I may answer, Yes, in bad waters, for there the data will be in excess, and there can be no reasonable doubt in our minds; but without more general information many polluted waters may be passed over, and apparently bad waters 